\title{
Entrepreneurship and Self-Employment: The State-of-the-Art and Directions for Future Research
}

\section{GiSeung Kim}

9 his survey overviews the literature on entrepreneurship and self-employment. The author catalogs the main contributions of this body of research and makes a distinction between issues on which there is now widespread agreement and those for which no consensus has yet emerged. This latter set of issues provides fertile ground for further research.

\section{Introduction}

Entrepreneurial activity is now recognized as a powerful engine of economic growth and innovation. Self-employment is an important source of new jobs and an alternative to paid employment. In fact, about 10 percent (OECD) of the total U.S. labor force is self-employed (and operate small businesses in general) to quickly and efficiently adjust to structural changes in the economy.

For these reasons, the study of entrepreneurship and selfemployment has increased in recent years. This literature review presents a brief outline of the major topics covered in theoretical and empirical studies on entrepreneurship and selfemployment. It is expected to help identify the direction of further research and the interpretation of numerous results.

Defining the words entrepreneur and entrepreneurship is one of the most difficult and intractable tasks faced by researchers in the field.There is a proliferation of theories, definitions, and taxonomies of entrepreneurship that are often in conflict and overlap with each other, resulting in confusion and disagreement among researchers and practitioners about precisely what entrepreneurship is. To cut through a paralyzing and ultimately fruitless debate, and to achieve consistency, we will adopt the following convention in this research. At the conceptual level, the terms entrepreneur and entrepreneurship will be used; at the practical level, where issues of measurement, estimation, and policy are involved, we will use the closest approximation to the manifestation of entrepreneurship that appears to be suitable. That will usually be selfemployment, though occasionally the term small firms will be more relevant. These two terms will be used interchangeably in this article.

This review begins with a discussion of the static analyses of the propensity to be self-employed, using cross-sectional data. This discussion is followed by dynamic analyses, which are subdivided into transition analysis, duration analysis, and time series analysis. Open questions and further research topics are suggested in the last section.
Static Analysis of Self-Employment Choice

Static analysis based on cross-sectional data usually examines the socioeconomic characteristics of self-employment using a discrete choice model. Most of the research in this category has investigated the following questions:

-What are the determinants of entrepreneurial choice?

-What makes a young entrepreneur?

- Who starts new firms?

-What critical factors enable people to become selfemployed?

- Are there any backgrounds and characteristics that distinguish successful entrepreneurs from both unsuccessful entrepreneurs and the larger group of nonentrepreneurs?

As a result, much of the work dealing with the self-employment decision has focused on personality, family circumstances, human capital (education, job experience, etc.), ethnic origin (immigrant issues), and financial capital (liquidity constraint issues).

The empirical studies vary greatly in the type of data they use. For example, Lunn and Steen (2005), Bruce and Schuetze (2004), Arum (2004), Edwards and Field-Hendrey (2002), Hout and Rosen (1999), Borjas (1986), Brock and Evans (1986), Borjas and Bronars (1989) and Evans and Leighton (1989) use samples from the U.S. labor market [Evans and Leighton (1989) also analyze the dynamic model in the same paper].

Henley (2005), Blanchflower and Oswald (1998) and Rees and Shah (1986) use samples from the U.K. labor market. Bernhardt (1994), Carrasco (1999) and Carroll and Mosakowski (1987) use samples from the Canadian, Spanish, and West German labor markets, respectively. Arenius and Minniti (2005), Müller and Arum (2004), Torrini (2005), Parker and Robson (2004) and Blanchflower (2000) carry out crosscountry comparisons in entrepreneurship and self-employment activities.

Sampling ages and groups are also different in each study. Most of the research focuses on 16-to 64-year-old white males. However, Borjas and Bronars (1989) separate their sample into White, Black, Asian, and Hispanic. Hout and Rosen (1999) and Blanchflower and Oswald (1998) focus on those between 25 and 64 years old, and those under age 33, respectively.

Moreover, particular business sectors are excluded from the estimating samples in a number of studies. For example, while Hout and Rosen (1999) include the agricultural sector, 
Borjas (1986), Brock and Evans (1986), Rees and Shah (1986), Borjas and Bronars (1989) and Bernhardt (1994) exclude the agricultural sector from their research. Brock and Evans (1986) and Bernhardt (1994) exclude professionals (e.g., doctors, dentists, lawyers, veterinarians, and other health professionals), part-time workers, and commission salespeople. These exclusions are made mainly to focus on situations where workers are likely to face the choice between selfemployment and wage/salary employment depicted in models of self-employment. In contrast, Lentz and Laband (1992) and Lentz and Laband (1989) only focus on professionals (lawyers and doctors).

Five different types of studies are distinguished on the basis of the main driving causes of the decision to become self-employed: personality, family circumstances, human capital, ethnic origin and immigrant background, and liquidity constraint. The empirical results of these cross-section studies are reviewed below.

\section{Personality}

Several personal characteristics-for instance, a high need for achievement, self-confidence, internal locus of control, risktaking, and personal values-have all been mentioned by researchers trying to identify what distinguishes selfemployed workers from paid workers. Beugelsdijk and Noorderhaven (2005) claim that entrepreneurs are more individually oriented than the rest of the population. Blanchflower and Oswald (1990) and Blanchflower and Meyer (1994) argue that entrepreneurial vision is one factor influencing the probability of an individual starting a business, as reflected in the personality of the entrepreneur at a young age. Blanchflower and Oswald also suggest that individuals are more likely to be self-employed if they were as a child hostile to others, but not unforthcoming or anxious for acceptance. However, Blanchflower and Oswald (1998) reexamined the impact of psychological traits on entrepreneurship. In this later paper, they found a single underlying factor: those who were anxious for acceptance were less likely to run their own business. However, the effect is quantitatively small. An individual's psychology apparently does not play a key role in determining who becomes an entrepreneur.

Other research on the personality of an entrepreneur was done by economic psychologists such as Chell, Haworth, and Brearley (1991). According to these authors, entrepreneurs are alert to business opportunities, proactive rather than reactive, innovative, imaginative, idea-people, agents of change, restless, adventurous, and adopters of broad financial strategies.

Internal locus of control was also occasionally tested as a determinant of becoming self-employed. It is assumed that individuals who possess a high level of "internal locus of control" are those willing to take charge of their own future. This trait is often associated with motivation or "entrepreneurial drive," which encourages self-employment. Evans and Leighton (1989) test this influence using an instrument called the Rotter test. ${ }^{1}$

Early works such as McClelland (1961) about personality as a determinant of self-employment argue that entrepreneurs are characterized by a "willingness to work" and a higher need for achievement (n-Achievement), which is more intense compared to other groups in society. Others, such as Kets de Vries (1977), conduct research based on interviews and the life histories of a number of entrepreneurs. Kets de Vries' work suggests that entrepreneurs often have an unhappy family background, leading to their inability to accept authority, and to work closely with others. This would appear to be the psychological basis for the "hostility" and "unforthcoming" variables of Blanchflower and Oswald (1990).

\section{Family Circumstances}

To address the question of why people choose to be selfemployed, some research has approached the self-employment choice from a family perspective. These studies have investigated how differences in family background affect the decision to be a self-employed person. It is generally accepted that the offspring of the self-employed display a greater inclination to become self-employed because they may take over the family business once their parent has retired. This intergenerational link between parents and offspring was first conjectured by Marshall (1930). He thought it was obvious that the son of a man already established in business starts with a great advantage over others.

Lentz and Laband (1990) and Stanworth et al. (1989) have placed particular emphasis on the intergenerational entrepreneur. They suggest that the probability of a young man becoming self-employed is significantly higher when his father is self-employed. In particular, analyzing data from a survey of more than 600 respondents, Stanworth et al. (1989) show that 30 percent to 47 percent of individuals either in business or considering to start one have a father who has also been in business. Lentz and Laband (1990) focused on the entrepreneurial success and occupational inheritance among proprietors, concluding that second-generation proprietors start their businesses at a significantly younger age, on average, than first-generation proprietors. More importantly, the former were found to commence their business careers with significantly greater quantity of managerial human capital than the latter. Thus, earnings capacity of followers will typically exceed that of nonfollowers, all other things being equal.

Not only is the self-employment status of one's father but also the father's occupation proved an influential factor in the self-employment decision of offspring. Evans and Leighton (1989) and Blanchflower and Oswald (1998) find that individuals have a higher propensity to become self-employed if 
their fathers are managers or farmers, and less likely to choose this employment status if their fathers are unskilled.

Two papers on intergenerational link in the choice of professional occupations (Lentz and Laband 1989; Lentz and Laband 1992) support the idea that family circumstances, particularly a parent's job, are very important in an offspring's job decision. Lentz and Laband (1989) reveal marginally greater probability of admittance into (at least one) medical school for children of doctors as compared to children of nondoctors. This fact can plausibly be explained as resulting from nepotism, in various forms, as well as from human capital transfers from first- to (would-be) second-generation doctors. Another paper (Lentz and Laband 1992) studied self-recruitment in the legal profession. In this paper, the authors argue that lawyers' sons follow in their parents' footsteps because the occupation lends itself to low-cost transfer of relevant skills and knowledge from one generation to the next, especially in the case of family law practices.

Schiller and Crewson (1997) isolate several dimensions of "nature" and "nurture" that affect both the supply of entrepreneurs and their later success. Using data from the National Longitudinal Surveys of Youth, the authors first determine who pursues self-employment in their youth and then who succeeds. There is a surprisingly high incidence of selfemployment but very low success rates. Role models (especially a managerial mother) are particularly critical to the supply of female entrepreneurs. Dunn and Holtz-Eakin (2000) and Hout and Rosen (1999) confirm earlier findings that family background is an important determinant of offspring's selfemployment outcomes. Dunn and Holtz-Eakin (2000) stress the experience and business success of a person's parent as a contributor in that person's decision to become selfemployed.

The effects of family structure (e.g., number of children) on self-employment are investigated by Carr (1996). He concludes that men and women respond in markedly different ways to the structure of the family and tradeoffs between wage/salary occupation and self-employment. More specifically, the presence of preschool children has been shown to have a large and positive effect on the odds that a woman will work as a self-employed childcare provider, while it has a negative effect for men. This can be explained by the fact that if women are concerned about combining work and family responsibilities, then self-employment may be viewed as a flexible and lower cost work option (see Connelly 1992b; Connelly 1992a).

\section{Human Capital (Education, Experience, Age)}

One of the major theoretical determinants of self-employment choice is human capital (see Table 1). In this category, economists would normally include education, experience in selfemployment, experience in salary/wage work, and age. The impact of human capital on self-employment choice can be explained using the Lucas (1978) model and similar models. In these models, human capital enhances an individual's managerial ability and hence increases the propensity to be selfemployed. On the other hand, it is possible that a higher level of education may facilitate entry into the wage/salary sector and thus lessen the likelihood of becoming self-employed. Regarding the tendency to be self-employed, the net impact of offsetting influences of the level of human capital cannot be determined a priori, and this appears to be reflected in the conflicting evidence from empirical studies.

Results in Rees and Shah (1986), Fujii and Hawley (1991), Evans and Leighton (1989) and Bates (1990) are consistent with the hypothesis that those with higher education are more likely to form their own firm than those with a lower education. In contrast, according to de Wit and van Winden (1989) and de Wit (1993), a high level of education deters entry into self-employment. Schiller and Crewson (1997) show that education does not affect male entry to selfemployment.

These different results may arise from different specifications of the estimating equations. For example, deWit and van Winden (1989) control for occupation status, a variable that is positively correlated with both educational attainment and the propensity to be self-employed.This implies that the omitted variables create a positive bias in the education coefficient in studies that do not control for occupational status. It follows, therefore, that studies that do not control for occupational status generally report a positive relationship between self-employment inclination and education. The contradictory result of Schiller and Crewson (1997), however, is attributed to a different reason. To explain, the data set used in this research includes only young men, and young people who are in college do not generally pursue self-employment. ${ }^{2}$

Another reason for the inconclusiveness of several researches on the relationship between education and entrepreneurship is that they are using a bi-lateral test. Very low and very high levels of education have a strong relationship with entrepreneurial activities. It could be explained that those insufficiently schooled often find their only means to success through the creation of new ventures.

The other human capital characteristics that an individual brings to entrepreneurship relate to work experience. ${ }^{3} \mathrm{~A}$ positive relationship between self-employment and work experience has been demonstrated by Schiller and Crewson (1997) and Bates (1990). Schiller and Crewson argue that work experience is positively correlated with performance even though conventional indices of human capital are negatively correlated with female self-employment. Bates obtains similar results and finds that among the human capital variables, individuals' managerial experience generally has a positive effect on an individual's propensity to become self-employed. 


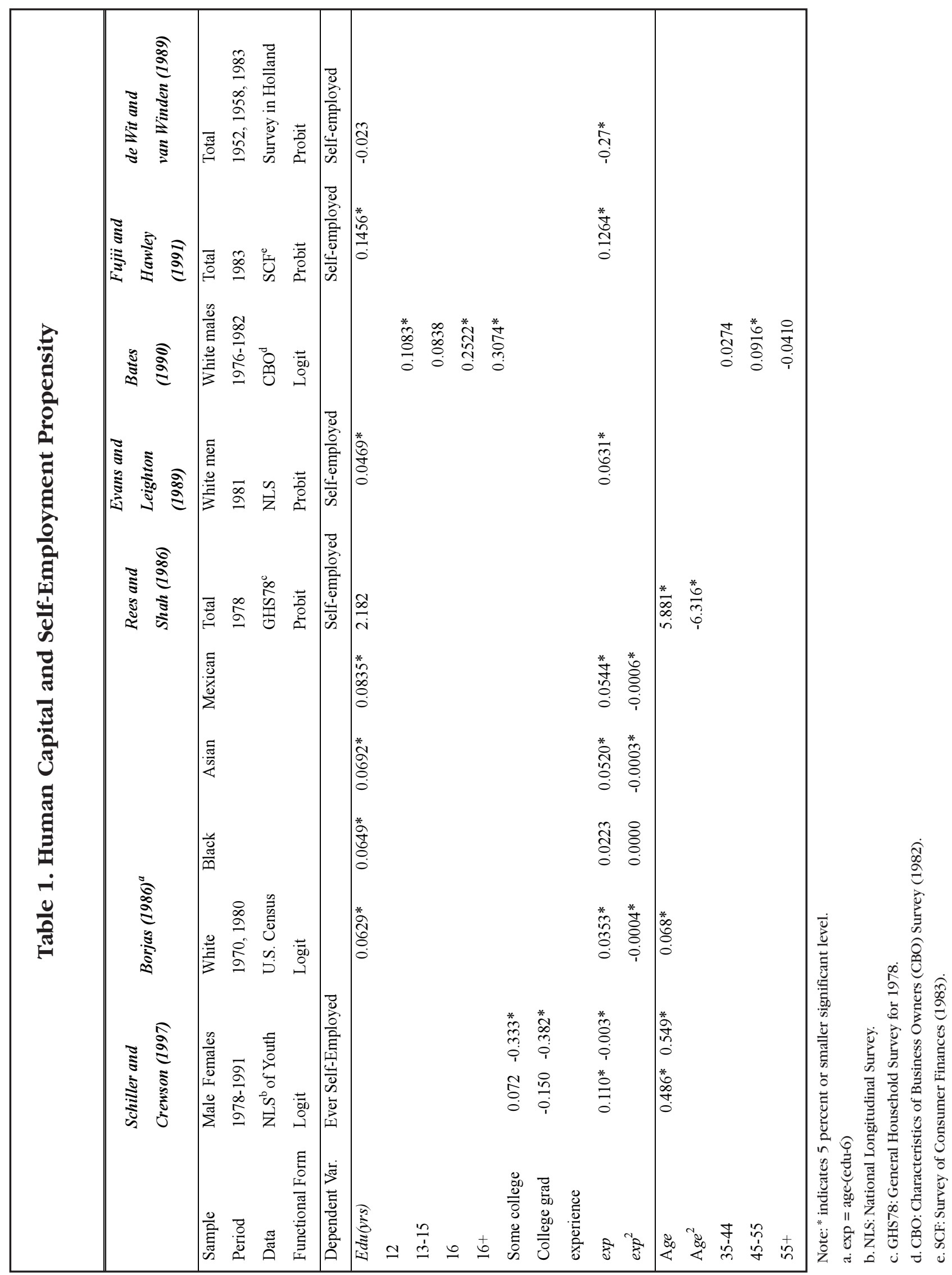

42 New EngLAND Journal of ENTREPRENEURShip 
Interesting research on the effect of human capital was conducted by Evans and Leighton (1989). They find that the probability of entering self-employment is independent of age or experience for the first 20 years of employment. This result is contrary to popular wisdom and inconsistent with Jovanovic's (1982) incomplete-information model and with standard job-shopping models of occupational choice, such as Johnson (1978) and Miller (1984), which predict that younger workers will try riskier occupations first. Jovanovic postulated that firms or individuals learn about their efficiency/ability as they operate in the industry or business. Efficient firms/individuals grow and survive; inefficient ones decline and fail. This implies that self-employed persons who are unsure of their own abilities at the beginning of a spell of self-employment will become aware of their suitability to self-employment through their experiences of success or failure. As time passes, the least able entrepreneurs realize their unsuitability and quit self-employment. These entrepreneurs who remain self-employed are more able, and therefore less likely to quit self-employment.

Other possible explanations of the self-employment effects associated with labor market experience are worth noting. For example, as labor market experience lengthens, an individual is able to accumulate the financial resources necessary for successful entrance into self-employment, and this financial capital factor, rather than human capital factors, explains the higher propensity for self-employment. Testing for labor experience in a self-employment model requires both information on labor market experience and information on financial capital. In fact, controlling for financial capital, Bernhardt (1994) reports that no statistical significance exists in the relationship between labor market experience and the propensity to be self-employed. Labor market experience may have a more minor role to play in the determination of self-employment status once liquidity constraints are accounted for.

\section{Etbnic Origin and Immigrant Background}

Another factor that has been argued to influence the choice between self-employment and paid employment is ethnic origin. Specifically, the analysis of self-employment among African Americans and other minorities is an issue that has received much attention in the self-employment literature.

Many authors, including Fairlie (1999), Fairlie (1994) and Borjas and Bronars (1989), have investigated why black selfemployed workers are underrepresented as a percentage of their population in comparison to whites. Using the Panel Study of Income Dynamics (PSID), Fairlie (1999) investigates why African-American males are one-third as likely to be self-employed as white males. He finds that racial differences in asset levels and probabilities of having selfemployed fathers explain a large part of the gap in the entry rate into self-employment.

Borjas and Bronars (1989) seek to explain the gap of white and black self-employment rates using a theoretical model incorporating consumer discrimination, whereby white consumers choose not to purchase goods and services from black-owned business [see Becker (1971) for consumer discrimination in detail.].

On the other hand, several authors (Lunn and Steen 2005; Clark and Drinkwater 2000; Fairlie and Meyer 1996; Yuengert 1995; and Borjas 1986) argue that self-employment is more common among immigrant groups. One of the reasons suggested by Borjas (1986) is the "enclave" effect. That is, a geographic enclave of immigrants increases self-employment opportunities for those immigrants who share the same national background (or language), and are residents of the enclave. In many cases, immigrant groups live in particular areas and have preferences for special goods and services that coethnics may have an advantage in providing. For example, Jewish entrepreneurs are better providers of kosher goods to other Jews, and Italians are better providers of pasta to other Italians. Yuengert (1995), Aldrich and Waldinger (1990), and Borjas and Bronars (1989), however, find little support for the enclave hypothesis and provide contrary evidence on the importance of ethnic enclaves.Yuengert (1995) and Borjas and Bronars (1989) provide empirical evidence that self-employment rates are no higher in cities with higher concentrations of immigrants. Aldrich and Waldinger (1990) cite a counter example of self-employment rates of Jews in the early in 1990s, in particular, with high Jewish selfemployment rates in areas outside the main enclave of New York City.These counter evidences are usually explained by a "competition with one another" in the enclave market.

Instead of the "enclave" hypothesis, Yuengert's (1995) results support the "home-country self-employment" hypothesis and the "tax avoidance" hypothesis. Immigrants from countries with high self-employment rates (who are therefore more likely to possess small business skills) are more likely to enter self-employment. Also, immigrants are more concentrated in high-tax states, where self-employment (with its greater opportunities for tax avoidance) is more prevalent.

Other causes of the high rate of self-employment in immigrant groups might be discriminations and their English language skills (see Moore 1983; Light 1979). Light argues that individuals who are disadvantaged in the labor market are more likely to start businesses. Discrimination may push some individuals into self-employment. In addition, language barriers and ignorance of customs may make self-employment more desirable than available wage work.

\section{Liquidity Constraint Issues}

One of the questions considered in the self-employment lit- 
erature is whether an individual who wants to establish a new business faces financial constraints (see Table 2). The basic issues of this research are the existence of liquidity constraints and the impact of the constraints on hindering people from starting a business. If financial markets work perfectly, then there should not be any constraints in borrowing to establish a new firm. However, financial markets are far from perfect, so not all entrepreneurs have access to collateral. Thus, some are unable to obtain financing, which results in more barriers-credit or liquidity constraints.

Many authors agree on the liquidity constraint hypothesis that is consistent with Knight's original thesis. For example, Meyer (1990) estimates logit equations using 1984 data from the survey of Income Program Participation (SIPP) and found that the probability of being self-employed increases with an individual's net worth, ceteris paribus. Similarly, Blanchflower and Oswald (1990) employ probit analysis to analyze the incidence of self-employment among a cross section of British males who were 23 years of age in 1981. The survey used in their research contained a question about the size of any gifts or inheritances that the respondent might ever have received and the response was included as an independent variable. The results suggest that such transfers are statistically significant and quantitatively important. They report that those who were given or inherited $\$ 5,000$ were approximately twice as likely to set up a business than a person who had received nothing.

Blanchflower and Oswald (1990) use a dataset of British males who were 23 years of age in 1981. It might be argued that age 23 is too young as a cutoff to study self-employment.
Hence, Blanchflower and Oswald (1998) reexamine the analysis for the 1991 sweep of the panel, at which point these individuals were up to 33 years old. They obtained results consistent with previous results. Blanchflower and Oswald (1998) also provide interview evidence on capital constraints. ${ }^{4}$

In a study of the Canadian labor market, Bernhardt (1994) employs three variables to measure financial resources: employment status of spouse, availability of investment income, and ownership of home. The impact of each of these variables reflecting financial resources is positive and significant, implying that liquidity constraints are a barrier to selfemployment. Recent work by Astbro and Berrihardt (2005) shows that the magnitude of credit constraint is conditioned by the relative productivity of human capital. Henley (2005) argues that housing wealth appears to be significantly associated with small business job creation.

Fazzari, Hubbard, and Petersen (1988) find evidence of significant capital market imperfections even for publicly traded manufacturing corporations. Evans and Jovanovic (1989) have developed and estimated a behavioral model of entrepreneurial choice under liquidity constraints. Their results reject Schumpeter's view that capital markets allow a separation of the entrepreneurial and capitalist functions (i.e., liquidity constraints bind). It is estimated that entrepreneurs are limited to a capital stock that is no more than about one and a half times their wealth. As a result, almost all the selfemployers in their sample are estimated to devote less capital to their business than they would like to. Moreover, the authors find a negative correlation between net family assets

\begin{tabular}{|c|c|c|c|c|}
\hline \multicolumn{5}{|c|}{ Table 2. Liquidity Constraints } \\
\hline & $\begin{array}{l}\text { Blanchflower and } \\
\text { Oswald (1990) }\end{array}$ & $\begin{array}{l}\text { Blanchflower and } \\
\text { Oswald (1998) }\end{array}$ & & $\begin{array}{l}\text { Bernhardt } \\
(1994)\end{array}$ \\
\hline Sample & Total & Males & Females & Total \\
\hline Period & 1981 & Age 23 in 1981 & Age 33 in 1981 & 1981 \\
\hline Data & $\mathrm{NCDS}^{\mathrm{a}}$ & NCDS & & $\mathrm{SCCP}^{\mathrm{b}}$ \\
\hline $\begin{array}{l}\text { Functional } \\
\text { Form }\end{array}$ & Probit & Probit & & probit \\
\hline Dependent var & Self-Employed & Self-Employed & & Self-Employed \\
\hline Inheritance & $0.117 *$ & $0.00016^{*}$ & $0.0012 *$ & \\
\hline Inheritance $^{2}$ & $-0.004^{*}$ & $-0.0041^{*}$ & $-0.0017^{*}$ & \\
\hline Spouse works & & & & $0.252 *$ \\
\hline Investment & & & & $0.0177^{*}$ \\
\hline income & & & & $0.273 *$ \\
\hline Own home & & & & \\
\hline
\end{tabular}


and (unobserved) entrepreneurial ability. This finding suggests that self-employers, particularly those with high ability, face binding financial constraints.

This negative correlation was thought theoretically implausible. Xu (1998) extends the Evans and Jovanovic model so that wealth is endogenized and shows that their result may be due to a downward bias in their wealth data. ${ }^{5}$ Using less-biased wealth data to reestimate the Evans and Jovanovic model, he found a positive correlation between wealth and ability, which is theoretically more justifiable. ${ }^{6}$ This article questions the significance, effect, and even the existence of a liquidity constraint.

In addition to the contradictory econometric results, measuring the effect or existence of liquidity constraints poses conceptual problems. Consider a hypothetical individual who desires to be self-employed but is currently capitalconstrained. Assume that over time, the individual amasses enough assets by decreasing consumption until he or she accumulates enough savings to pursue self-employment. The observed action of entering self-employment without "outside" help would generally be considered evidence that individuals are not capital-constrained in the long run. The conclusion could be drawn that liquidity constraints are not binding because individuals are able to amass the necessary funds without outside intervention. Yet the reason for the high savings over time may have been that financial capital was not available to the individual, necessitating a postponement of start-up. It is difficult to uncover which individuals in a given year of a sample are actually "peers" with respect to liquidity constraint.An individual who saves a higher fraction of yearly income from all sources will build up savings and assets and will appear to be "unconstrained," while another individual with the same yearly income and initial endowment but a low savings rate may appear "constrained." Such conceptual and practical problems help explain the varied results researchers report with respect to the liquidity constraint.

The advantage of using cross-sectional methods is that the study requires only a single survey. Cross-sectional statistics provide a snapshot of the self-employed at a given point in time. They are also valuable tools for describing the popula- tion of self-employed individuals.

However, cross-sectional data studies suffer from several drawbacks. First, cross-sectional studies do not yield information on self-employment behavior over time. Second, crosssectional data do not provide a great deal of insight into the creation and discontinuation of small businesses. Since no business start-ups or dissolutions are observed, there is no way to examine the factors that influence these events. Third, potentially severe endogeneity problems can arise with the use of cross-sectional data. Fourth, the probability of being self-employed at a point in time, $t$, depends on the underlying probability of switching into self-employment at some previous time and surviving until time $t$. The cross-sectional estimates confound the determinants of entry and survival.

\section{Dynamics of Self-Employment Choice}

The static model of self-employment using cross-sectional data has failed to explain the determinants of switching into and out of self-employment, and the growth and survival from such a venture. This limitation is addressed by several studies of dynamic self-employment. These can be distinguished into studies using transition analysis and those using duration models.

\section{Transition Analysis}

To examine the propensity for individuals to enter or leave self-employment, some authors have used transition matrix analysis. Fairlie (1999) and Evans and Leighton (1989) have calculated the transition rates into and out of self-employment in the United States (see Table 3). Estimates by Fairlie (1999), using PSID data, indicate that black men enter selfemployment from wage/salary work at a much lower rate than white men (2.02\% compared to $3.95 \%)$. In addition, black men exit from self-employment at a much higher rate than white men (36.64\% compared to $18.51 \%)$. Evans and Leighton (1989) also report similar estimates using the oneyear transition rates of white males in their sample. They estimate entry rates of 4.0 percent and 2.5 percent and exit rates of 13.8 percent and 21.6 percent using data from the National Longitudinal Survey of Young Men for 1966-1981 and the Current Population Surveys for 1968-1987, respec-

\begin{tabular}{|lllll|}
\hline \multicolumn{5}{c|}{ Table 3. Transition Rates } \\
\hline \hline & Fairlie (1999) & $\begin{array}{l}\text { Evans and } \\
\text { Leighton (1989) }\end{array}$ & \\
\hline $\begin{array}{l}\text { Data } \\
\text { Sample }\end{array}$ & $\begin{array}{l}\text { PSID } \\
\text { Black }\end{array}$ & $\begin{array}{l}\text { Males } \\
\text { White }\end{array}$ & $\begin{array}{l}\text { NLSY, 66-81 } \\
\text { White Mn }\end{array}$ & $\begin{array}{l}\text { CPS, 68-87 } \\
\text { White Men }\end{array}$ \\
\hline $\begin{array}{l}\text { Transition rate into } \\
\text { self-employment } \\
\begin{array}{l}\text { Transition rate out of } \\
\text { self-employment }\end{array}\end{array} 2.07$ & 3.95 & 4.0 & 2.5 \\
\hline
\end{tabular}


tively. Kuhn and Schuetze (2001) also showed the transition patterns of self-employment using the Canadian Survey of Consumer Finances.

These transition matrices are highly useful for characterizing the percentage of a certain population switching between different employment modes in two particular surveys. However, a rich set of covariates cannot be easily incorporated into transition matrix analyses. Thus, transition analysis fails to explain the determinants of entry into and exit from self-employment. To study the factors influencing transitions to self-employment, several studies employ a variety of panel data techniques, including binary logit or probit models and/or multinomial logit models. The advantage of logit or probit models over simple transition matrix analysis is that individual characteristics are incorporated into the model.

A summary of the key findings of these studies follows. These findings are organized on the basis of the characteristics used as determinants of the entry into and exit from selfemployment.

Dunn and Holtz-Eakin (2000) investigate the relative importance of family financial and human capital in the transition to self-employment. In particular, they estimate the impact of an individual's own wealth, human capital, parental wealth, and self-employment experience on the probability that an individual transit from wage/salary to self-employment. Fairlie (1999) examines the causes of racial differences in both the transition rate into, and the transition out of, self-employment. Specifically, he examines the extent to which racial differences in education, asset levels, parental financial resources, and parental self-employment contribute to the black/white gap in the entry, exit, and selfemployment rates. Carrasco (1999) focuses on estimating the effect of being unemployed on the probability of starting a business and on self-employment duration, using longitudinal data from the Spanish Continuous Family Expenditure Survey (ECPF) for 1985 to 1991 . He also analyzes the effect of capital and unemployment benefits on the probability of transition. Carrasco's (1999) purpose is to study the factors influencing the decision to enter into selfemployment and the likelihood of remaining in business. One of the principal findings is that unemployed individuals are more likely to switch into self-employment, a finding consistent with the view that the disadvantaged tend to become self-employed. Also, he finds that receiving unemployment benefits reduces the probability of entering selfemployment.

The focus of Blanchflower and Meyer (1994) is the transition of Australian and U.S. youth (age 16-25 years) from wage/salary employment into self-employment. The focus of Bates' (1990) study is to determine the empirical relevance of Lucas' (1978) hypothesis on managerial ability and entrepre- neurship, and Jovanovic's (1982) hypothesis regarding individuals' learning ability and business survival. Evans and Jovanovic (1989) and Evans and Leighton (1989) look at the roles of education and liquidity constraints on transition in and out of self-employment. Carroll and Mosakowski (1987) focus on the process of entry into self-employment at various stages of a person's career, and career differences between the self-employed and the conventionally employed.

The determinants of employment choice that are emphasized in transition analysis on self-employment are similar to those discussed in cross-sectional analyses. Among these are educational attainment, labor market experience, liquidity constraints, and income.

\section{Years of Education}

Educational attainment is a key determinant of the propensity to be self-employed. Unlike the conflicting results obtained in cross-section studies, this variable in longitudinalbased studies generally positively affects the probability of entering self-employment. However, the levels of significance differ across studies. Evans and Jovanovic (1989) and Evans and Leighton (1989) report that the education effect on transition to self-employment is insignificant. In comparison, Blanchflower and Meyer (1994) show a positive and significant relationship between years of education and the transition to self-employment using U.S. labor market data. ${ }^{\top}$ The difference in significance levels may be due to the time element introduced into the study with the use of longitudinal data, but it is more likely to be due to the correlation between educational attainment and financial capital (Bates 1990). The financial capital structure of small businesses at the point of start up could be considered as an endogenous variable. Specifically, education level is a major determinant of the loan amounts that commercial banks extend to small business formations.

\section{Labor Market Experience}

Labor market experience is significant in determining an individual's inclination to switch from wage/salary employment to self-employment. Using age and age-squared as a measure of experience in labor markets, Blanchflower and Meyer (1994) find that the transition to self-employment is significantly influenced by labor market experience for youth in the Australian labor market. Mixed results are reported, however, when more refined measures (i.e., wage experience and self-employment experience) of labor market experience are used. For instance, Evans and Leighton (1989) report that previous self-employment experience has a positive and significant impact on the transition to self-employment, while the impact of previous wage experience on switching to self-employment is not significant at conventional levels. 
This is consistent with Jovanovic's (1982) proposition that individuals are able to learn from past experience, and that experience accumulated in the self-employment sector will be more useful to their employment decisions. Accordingly, a long experience in self-employment indicates that the individual is effective and has strong ability. On the contrary, Evans and Jovanovic (1989) report that the coefficient on previous wage/salary experience is positive and significant, though they did not consider self-employment experience. The general finding from these results, therefore, is that experience affects employment choice, and that labor market experience accumulated in the self-employment sector is particularly relevant in explaining the transition to the selfemployment or entrepreneurial sector.

\section{Financial Capital and Income}

Several longitudinal studies of self-employment have tested the importance of the availability of capital when an entrepreneur starts a new business. Most longitudinal studies are consistent with the hypothesis that entrepreneurial activity is restricted by liquidity constraints, either by preventing firm entry (Evans and Jovanovic 1989; Evans and Leighton 1989; Holtz-Eakin, Joulfaian, and Rosen 1994b; Blanchflower and Oswald 1998; Carrasco 1999) or by affecting firm longevity (Evans and Leighton 1989; Bates 1990; Holtz-Eakin, Joulfaian, and Rosen 1994a).

Evans and Leighton (1989) study the individual determinants of observed switches from wage employment to selfemployment and compare these results to their findings on selection and earnings. One of their key findings is that the availability of more assets results in a higher probability of switching from wage employment to self-employment.

The dynamic studies of Carrasco (1999) and Evans and Jovanovic (1989) aim at determining whether liquidity constraints play a role in the decision process to become an entrepreneur (and to start at the most profitable scale). They find empirical support for binding liquidity constraints, as capital assets have a positive effect on the wage-worker's probability to start a business.

To test whether an individual's wealth affects the probability of becoming an entrepreneur and, conditional on becoming an entrepreneur, whether liquidity constraints affect the viability of entrepreneurial enterprises, Holtz-Eakin, Joulfaian, and Rosen (1994b), Holtz-Eakin, Joulfaian, and Rosen (1994a) employ a sample of people who received inheritance using tax return data.They find that the probability of becoming an entrepreneur rises with the size of the inheritance. They also show that receiving an inheritance increases the probability that self-employed individual will stay in business rather than become a wage earner.

Evans and Jovanovic (1989) and Evans and Leighton (1989) report a nonmonotonic relationship between family net worth and the transition to self-employment. Initially, an increase of the individual's net worth increases the propensity to enter into self-employment. However, beyond a certain level, an increase in net worth decreases transition to selfemployment status. Nonmonotonicity might be explained by the diminishing importance of net worth and liquidity constraints.As wealth increases, the importance of any initial constraint diminishes, though the impact in this regard is relatively more important at low levels of wealth. It also might be the case that as an individual's net wealth increases, the degree of risk aversion rises. Because self-employment is assumed to be risky, individuals may hesitate to switch to self-employment.

An individual's earnings may also influence entry into selfemployment. The effects of earning can be derived through variables for personal income or the minimum wage. Studies by Evans and Jovanovic (1989), Evans and Leighton (1989) and Blanchflower and Meyer (1994) all found that individuals with relatively low wages are more likely to switch into self-employment.

The impacts of other variables have been analyzed in longitudinal studies, including tax policy, marital status, industry of occupation, and physical disability. ${ }^{8}$ With regard to tax policy, it has been considered that progressive taxation could, in principle, encourage entry via insurance for risk-averse entrepreneurs through the tax system or through offering greater incentives to avoid taxes on self-employment income. However, Gentry and Hubbard (2000) find no evidence to support such claims. Their empirical results using PSID imply a significant increase in entrepreneurial entry when tax rates are less progressive. In the case of marital status, the estimated effect of using longitudinal data (negative and significant) differs from that obtained using cross-sectional data. On the contrary, the effect of occupation on self-employment decision remains the same across different types of analysis with individuals employed in wholesale and retail trade, personal services, construction, and agriculture possessing a higher propensity to be self-employed than those working in administrative jobs (e.g., clerical).

\section{Duration Analysis or Hazard Model Analysis}

Studies using discrete choice models properly characterize the propensity for individuals to begin or quit self-employment. However, discrete choice models do not easily provide information about the duration dependence of self-employment failure rates.

Estimates of the duration dependence can be obtained from a hazard model analysis and have an explicit interpretation within the context of self-employment theory. For example, Jovanovic (1982), Jovanovic (1979) and Miller (1984) have put forward theories of job matching which imply entrepreneurs who remain self-employed for a long time are 
more able, and are therefore less likely to quit self-employment. Characterizing the duration dependence of selfemployment rate is a step toward understanding the dynamics of entrepreneurship.

Carrasco (1999) constructed a self-employment model using discrete survival analysis. He used semiparametric methods for maximum likelihood estimation of single-risk models with unrestricted base-line hazards by specifying duration dependence in a flexible way. He then estimated a competing risks model to distinguish exit into employment from exit into unemployment.The paper's main conclusion is that the probability of departing from self-employment decreases with duration in self-employment.

Evans and Leighton (1989) also obtained similar results on duration dependence for self-employment, using nonparametric hazard estimators to find that the probability of leaving self-employment declines with the length of time an individual is self-employed. They used data for 460 NLS white men who were observed from the time of entry to the end of the survey.They found that the hazard rate decreases with the duration in self-employment, falling from about 10 percent in the early years to 0 percent by the 11 th year in selfemployment.

Carroll and Mosakowski (1987) use the proportional hazards model of Cox (1972) to study the dynamics of selfemployment. Instead of making the duration dependence model explicitly, they focus on the contribution of the substantive variables to self-employment behavior-not the duration dependence of this behavior.They examine data on the propensity of West German individuals to become selfemployed and show that the probability of a person entering into self-employment at any stage in the life cycle is heavily dependent on prior engagement in self-employment or family employment.

\section{Time Series Analysis}

Time series analysis uses yearly aggregate or cross-sectional data and examines self-employment behavior over time. One of the few such studies was done by Blau (1987). The focus of Blau's work is to determine the causes behind the changes in self-employment rate using a general equilibrium model and the data from the Current Population Survey (CPS). In this paper, changes in technology, industrial structure, tax rates, and Social Security retirement benefits were indicated as the main causes of changes in self-employment rate. Devine (1994) also used time series data from the CPS to investigate the causes of the rise in female self-employment rate.

\section{Conclusion and Directions for Future Research}

This brief outline of major issues of theoretical and empirical entrepreneurship (self-employment) reveals that several characteristics have been generally agreed upon as determinants of self-employment, but that some issues remain controversial. One might consider the debate having been settled with regard to the set of determining factors, while the second set of remaining factors provides opportunities for further research. The following is a short overview of the set of issues for which there is widespread agreement and a contrast with those for which consensus is yet to be reached.

Empirical evidence indicates that father's self-employment status is a significant determinant of self-employment choice among offspring. Consequently, the son or daughter of the self-employed displays a greater propensity to become an entrepreneur. However, it is not known whether the offspring of such parents has a higher probability to succeed once he or she enters into self-employment.

Many authors agree on the liquidity constraint hypothesis consistent with Knight's thesis that bearing risk is one of the essential characteristics of self-employment. This consensus views the initial amount of capital as a very important factor of being self-employed. It also suggests that capital markets provide too little capital to self-employed individuals due to problems of moral hazard and adverse selection.

In comparison, the estimated impact of educational attainment differs across studies. The positive effect of education on self-employment probabilities can be explained by Lucas' (1978) model that human capital enhances an individual's managerial ability and hence increases the proclivity to be self-employed.A negative effect may result if a higher level of education facilitates entry into the wage sector and thus reduces the likelihood of becoming self-employed. Labor market experience has been shown to be significant in determining the individual's propensity to switch from wage employment to self-employment. Also, many studies report negative and significant impacts of self-employment duration on exit (entry) hazard rates.These results support Jovanovic's (1982) "learning model," which postulates that individuals (or firms) are able to learn from past experience whether they have ability in their current job, and experience accumulated is useful to the next job choice or business choice. The general theme is that labor market experience affects employment choice, and that experience accumulated in the selfemployment sector is particularly relevant in explaining entrepreneurial entry decisions.

It is generally accepted that African-Americans have a lower probability of becoming self-employed than whites. Asset levels and probabilities of having self-employed fathers are posited as explanations of the gap between the two selfemployment rates. In addition, there is a small but important set of studies that demonstrate that ethnic enclaves influence the self-employment choice of immigrant groups. These studies show that ethnic enclaves provide a market for selfemployed immigrants where they can cater to other individ- 
uals from the same ethnic background. In this context, the segregation of immigrants from the general community encourages self-employment and helps ease the transition to self-employment for newly arrived immigrants.

Empirical studies of self-employment have provided a solid basis for understanding the determinants of employment status. Most of the research is based on simple static models of self-employment. Because of data limitations, only a small portion of this research is focused on the dynamic analysis using longitudinal data. Several articles have suggested that cross-sectional analysis is not the most suitable method for the study of self-employment. To wit, Meyer (1990) argues that a superior approach is to use longitudinal data to examine self-employment. Additional work using dynamic analysis is needed to enhance our understanding of the self-employment process.

In particular, cross-section analyses have examined the determinants of entry into self-employment (i.e., the entrepreneurial sector). These studies, however, tend to look at the proportion of people who are self-employed individuals at any given point in time. They show that some groups, such as white males and older educated individuals, are more likely to be self-employed than other groups. They do not show, however, the extent of turnover in the self-employment group; that is, whether individuals move in and out of selfemployment or are self-employed for a long period of time. They also do not show whether differences in self-employment rates between groups is primarily due to their different propensity to enter self-employment or due to their different persistence once they enter. In other words, it is not known whether white males are more likely to be self-employed because they are more likely to try self-employment (compared to other groups) or because they are more likely to succeed in self-employment once they try (again, compared to other groups). Similarly, we do not know whether older educated individuals are more self-employed because they tend to be more successful or because they are more likely to pursue entrepreneurial activities. More research will be needed to address these issues by studying the dynamics of self-employment.

Finally, more needs to be known about who succeed in small businesses. People who become successful selfemployed may differ in a variety of unmeasured ways from those unsuccessful self-employed individuals. Entrepreneurial ability may come from "nature" or "nurture" or both. Questions about the effects of "nature" on entrepreneurial ability are important and interesting aspects of any such research.

\section{Acknowledgment}

The author wishes to thank George Deltas for advice and support. All errors are those of the author.

\section{Endnotes}

1.The standard Rotter test consists of an internal-external scale. This is a measure of perceived "locus of control," where the individual believes he or she is in charge of his or her destiny (internal), or it is determined by forces beyond his other control (external). The test comprises of a number of questions, and two choices (reflecting internal and external beliefs) are provided for each question.The respondent is asked to select the choice he or she believes to be true.The Rotter score is calculated as the total number of external choices made by the respondent. The Rotter test score may be related to personal, social, or cultural variables.

2.The NLSY covers only the early stages of the work-life cycle, up to age 35 in 1991.

3. In most cases, indirect measures of work experience were used. Some researchers used the individual's age as a proxy for labor market experience. Sometimes labor market experience is computed from information on the individual's age and years of education. For example, experience $=($ age - years of education - 5 or 6$)$.

4.They analyze two surveys. The first is the British Social Attitudes (BSA) Survey series, an annual random sample providing data from 1983 to 1989 . The second is the National Survey of the Self-Employed (NSS), a 1987 government-sponsored random sample of approximately 12,000 adults interviewed in Britain in the spring of 1987.

5.Xu (1998) argues that many individuals did not report full asset information, which caused a downward bias of wealth in the National Longitudinal Survey dataset used by Evans and Jovanovic (1989).

6. Xu (1998) includes only individuals who reported full asset information.

7. However, they do not show a significant influence of additional years of schooling on the probability of being self-employed in the Australian labor market.

8. See the findings of Gentry and Hubbard (2000), Fairlie (1999), Blanchflower and Meyer (1994), Bernhardt (1994), Evans and Jovanovic (1989) and Evans and Leighton (1989) for details.

\section{References}

Aldrich, H. and R. Waldinger. 1990. Ethnicity and entrepreneurship. Annual Review of Sociology 16, 111-135.

Arenius, P., and M. Minniti. 2005. Perceptual variables and nascent entrepreneurship. Small Business Economics 24, 3: 233-247.

Arum, R. 2004. Entrepreneurs and laborers:Two sides of self-employment activity in the United States. In The Reemergence of Self-Employment:A Comparative Study of Self-Employment Dynamics and Social Inequality. W. M_ller and R.Arum, eds. Princeton University Press. 
Astbro, T., and I. Bernhardt. 2005. The winner's curse of human capital. Small Business Economics 24, 63-78.

Bates, T. 1990. Entrepreneur human capital inputs and small business longevity. Review of Economics and Statistics 72 , 551-559.

Becker, G. S. 1971. The economics of discrimination. Chicago: University of Chicago.

Bernhardt, I. 1994. Comparative advantage in self-employment and paid work. Canadian Journal of Economics 27: $273-289$.

Beugelsdijk, S., and N. Noorderhaven. 2005. Personality characteristics of self-employed; an empirical study. Small Business Economics 24: 159-167.

Blanchflower, D. G. 2000. Self-employment in OECD countries. Labour Economics 7, 5: 471-505.

Blanchflower, D. G., and B. D. Meyer. 1994.A longitudinal analysis of the young self-employed in Australia and the United States. Small Business Economics 6:1-19.

Blanchflower, D. G., and A. J. Oswald. 1998. What makes an entrepreneur? Journal of Labor Economics 16: $26-60$.

Blanchflower, D. G., and A. J. Oswald. 1990. What makes a young entrepreneur? National Bureau of Economic Research Working Paper No. 3252.

Blau, D. M. 1987.A time-series analysis of self-employment in the United State.Journal of Political Economy 95, $445-467$.

Borjas, G.. 1986. The self-employment experience of immigrants. Journal of Human Resources 21: $487-506$.

Borjas, G., and S. G. Bronars. 1989. Consumer discrimination and self-employment.Journal of Political Economy 97: $581-605$.

Brock, W.A., and D. S. Evans. 1986. The economics of small business: Their role and regulation in the U.S. economy. New York: Holmes and Meier.

Bruce, D., and H. J. Schuetze. 2004. The labor market consequences of experience in self-employment. Labour Economics 11, 5: 575-598.

Carr, D. 1996. Two paths to self-employment? Women's and men's self-employment in the United States, 1980. Work and Occupations 23, 26-53.

Carrasco R. 1999. Transitions to and from self-employment in Spain:An empirical analysis. Oxford Bulletin of Economics and Statistics 61:315-341.

Carroll, G. R., and E. Mosakowski. 1987.The career dynamics of self-employment. Administrative Science Quarterly 32: 570-589.

Chell, E., J. Haworth, and S. Brearley. 1991. The entrepreneurial personality: Concepts, cases and categories. London and New York: Routledge.

Clark, K. and S. Drinkwater. 2000. Pushed out or pulled in? Self-employment among ethnic minorities in England and Wales. Labour Economics 7, 603-628.

Connelly R. 1992a. The effect of child care costs on married women's labor force participation. Review of Economics and Statistics 74, 83-90.

Connelly R. 1992b. Self-employment and providing child care. Demography 29, 17-29.

Cox, D. R. 1972. Regression models and life tables.Journal of the Royal Statistical Society (B) 34, 187-200.

de Wit, G. 1993. Determinants of self-employment. Heidelberg: Physia-Verlag.

de Wit, G.. and F.A.A.M. van Winden. 1989.An empirical analysis of self-employment in the Netherlands. Small Business Economics 1, 263-272.

Devine, T. J. 1994. Changes in wage-and-salary returns to skill and the recent rise in female self-employment. American Economic Review. 84, 108-113.

Dunn,T., and D. Holtz-Eakin. 2000. Financial capital, human capital, and the transition to self-employment: Evidence from intergenerational links. Journal of Labor Economics 18, 282-305.

Edwards, Linda N., and Elizabeth Field-Hendrey. 2002. Home-based work and women's labor force decisions. Journal of Labor Economics 20, 1:170-200.

Evans, D. S., and B. Jovanovic. 1989. An estimated model of entrepreneurial choice under liquidity constraints.Journal of Political Economy 97, 808-827. 
Evans, D. S., and L. S. Leighton. 1989. Some empirical aspects of entrepreneurship. American Economic Review 79:519-535. Fairlie, R.W. 1994. Three essays on ethnic and racial self-employment. Ph.D. thesis, Northwestern University.

Fairlie, R.W. 1999. The absence of the African-American owned business:An analysis of the dynamics of self-employment. Journal of Labor Economics 17, 80-108.

Fairlie, R.W., and B. D. Meyer. 1996. Ethnic and racial self-employment differences and possible explanations. Journal of Human Resources 31, 757-793.

Fazzari, S. M., R. G. Hubbard, and B. C. Petersen. 1988. Financing constraints and corporate investment. Brookings Papers on Economic Activity 1, 141-195.

Fujii, E.T., and C.B. Hawley. 1991. Empirical aspects of self-employment. Economics Letters 36, 323-329.

Gentry, W. M. and R. G. Hubbard. 2000. Tax policy and entrepreneurial entry. American Economic Review 90, 283-287.

Henley, Andrew. 2005. Job creation by the self-employed:The roles of entrepreneurial and financial capital. Small Business Economics 25, 2: 175-196.

Holtz-Eakin, D., D. Joulfaian, and H. S. Rosen. 1994a. Sticking it out: Entrepreneurial survival and liquidity constraints. Journal of Political Economy 102, 53-75.

Holtz-Eakin, D., D. Joulfaian, and H. S. Rosen. 1994b. Entrepreneurial decisions and liquidity constraints. Rand Journal of Economics 25, 334-347.

Hout, M., and H. S. Rosen. 1999. Self-employment, family background, and race. NBER Working Paper No. 7344.

Johnson, W. R. 1978. A theory of job shopping. Quarterly Journal of Economics 92, 261-277.

Jovanovic, B. 1979. Job matching and the theory of turnover.Journal of Political Economy 87, 972-990.

Jovanovic, B. 1982. Selection and the evolution of industry. Econometrica 50, 649-670.

Kets de Vries, M. 1977. The entrepreneurial personality: A person at the crossroads. Journal of Management Studies 14: $34-57$.

Kuhn, P. J., and H. J. Schuetze. 2001. Self-employment dynamics and self-employment trends: A study of Canadian men and women, 1982-1998. Canadian Journal of Economics 34, 760-784.

Laband, D. N., and B. F. Lentz. 1992. Self-recruitment in the legal profession. Journal of Labor Economics 10: 182-201.

Lentz, B. F., and D. N. Laband. 1989. Why so many children of doctors become doctors: Nepotism vs. human capital transfers. Journal of Human Resources 24: 396-413.

Lentz, B. F., and D. N. Laband. 1990. Entrepreneurial success and occupational inheritance among proprietors. Canadian Journal of Economics 23: 563-579.

Light, I. 1979. Disadvantaged minorities in self-employment. International Journal of Comparative Sociology 20, 31-45.

Lucas, R. E. 1978. On the size distribution of business firms. Bell Journal of Economics 9, 508-523.

Lunn, John, and Todd, Steen. 2005. The heterogeneity of self-employment:The example of Asians in the United States. Small Business Economics 24, 2: 143-158.

Marshall, Alfred. 1930. Principles of economics. London: Macmillan and Co.

McClelland, D. C. 1961. The achieving society. D. Van Nostrand Company, Inc.

Meyer, B. D. 1990. Why are there so few black entrepreneurs? NBER Working Paper, No. 3537.

Miller, R.A. 1984. Job matching and occupational choice. Journal of Political Economy 92, 1086-1120.

Moore, R. L. 1983. Employer discrimination: Evidence from self-employed workers. Review of Economics and Statistics 65, 496-501.

Müller,W., and R.Arum. 2004. Self-employment dynamics in advanced economies. In The Reemergence of Self-Employment:A Comparative Study of Self-Employment Dynamics and Social Inequality. W. M_ller and R.Arum, eds. Princeton University Press.

OECD, Labour Force Statistics, issues 1980-2005.

Parker, S. C., and M.T. Robson. 2005. Explaining international variations in self-employment: Evidence from a panel of OECD countries. Southern Economic Journal 71, 2: 287-301. 
Rees H., and A. Shah. 1986. An empirical analysis of self-employment in the U.K.Journal of Applied Econometrics 1: 95-108. Schiller, B. R., and P. E. Crewson. 1997. Entrepreneurial origins:A longitudinal inquiry. Economic Inquiry 35, $523-531$.

Stanworth, J., C. B. Stanworth, B. Granger, and S. Blyth. 1989. Who becomes an entrepreneur?" International Small Business Journal 8, 11-22.

Torrini, R. 2005. Cross-country differences in self-employment rates:The role of institutions. Labour Economics 12, 5: 661-683.

$\mathrm{Xu}$, B. 1998. A reestimation of the Evans-Jovanovic entrepreneurial choice model. Economics Letters 58, $91-95$.

Yuengert,A. M. 1995. Testing hypotheses of immigrant self-employment.Journal of Human Resources 30, $194-204$.

\section{About the Author}

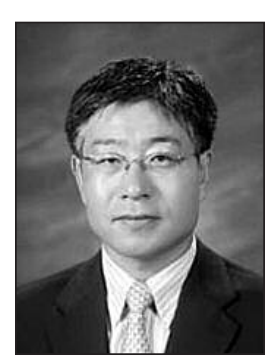

GISEUNG KIM (gskim@cju.ac.kr) is a professor of economics at Cheongju University, South Korea. He earned his Ph.D. in economics at University of Illinois at Urbana-Champaign in 2001. His areas of teaching and research are labor economics, entrepreneurship, and small businesses. His research has been published in several journals, including the Quarterly Review of Economics and Finance, Journal of Korean Economic Studies, Korean Journal of Economics, and Journal of Vocational Education E Training. Prior to his academic career, Dr. Kim was a director of the economic policy research division in National Assembly Budget Office, Republic of Korea, and a research fellow of LG Economic Research Institute. 